\title{
Development of Anopheles sinensis immatures (Diptera: Culicidae) in the field: effects of temperature and nutrition
}

\author{
Motoyoshi Mogr and Takao Okazawa \\ Division of Parasitology, Department of Microbiology, Saga Medical School, \\ Nabeshima 5-1-1, Saga, 849 Japan
}

(Received: 22 July 1996; Accepted: 21 October 1996)

\begin{abstract}
Key words: Anopheles sinensis, immature development, temperature, nutrition
\end{abstract}
\begin{abstract}
Development of Anopheles sinensis larvae and pupae was studied in net cages floated in rice fields or a swamp from March through November in Saga, southwest Japan. Food supply shortened larval durations, indicating that nutrition was suboptimal in the field condition. The development threshold and thermal constant for larvae were ca. $10^{\circ} \mathrm{C}$ and 164 day-degrees, respectively, and those for pupae ca. $6^{\circ} \mathrm{C}$ and 38 day-degrees. Proportions of instar durations to the whole larval duration were independent from temperature and nutrition. Empirical equations were given for estimating temperatures at the water surface (microhabitat of anopheline immatures) in rice fields from air temperatures.
\end{abstract}

\section{INTRODUCTION}

Anopheles sinensis Wiedemann is a dominant rice field mosquito in east Asia and has been incriminated as a vector of filariasis and malaria in part of China (Harrison and Scanlon, 1975). There are many reports on seasonal dynamics of populations of $A n$. sinensis larvae or adults from various localities in its distribution ranging from north temperate regions to the tropics (WHO, 1989). Nevertheless, processes underlying the seasonal dynamics have not been analyzed, due partly to the lack of data on development durations required for life-table analyses.

Since Huffaker's (1944) classical work on Anopheles quadrimaculatus Say, effects of temperature on anopheline development have been studied in the laboratory for some malaria vectors. However, analyses of field data with laboratory developmental parameters need caution, because anopheline development in the field may be either accelerated by cyclic temperature (Huffaker, 1994) or decelerated by suboptimal nutrition (Mogi et al., 1984, 1986). Furthermore, temperatures of shallow and open water in rice fields rise above air temperatures by $3-5^{\circ} \mathrm{C}$ (Mogi, 1978). Description of the relationship between temperature and development in the field also is a prerequisite for the prediction of possible effects of global warming on seasonal activities and geographical distribution of disease vectors (WHO, 1990). This report presents basic information about the development of $A n$. sinensis immatures in the field, which may be utilized for analyzing and predicting temporal and spatial dynamics of the species.

\section{Materials And Methods}

Mosquitoes. Blood-fed females of $A n$. sinensis were collected at a cowshed in Nabeshima, Saga City, northern Kyusyu, by aspirators around $20-21 \mathrm{~h}$. They were provided with $2 \%$ sugar solution soaked 
on cotton balls under $27^{\circ} \mathrm{C}, 80 \%$ R.H. and a photoperiod of $16 \mathrm{~L}: 8 \mathrm{D}$. Approximately 5 days after the collection, a black, plastic oviposition cup $(10 \mathrm{~cm}$ diameter, $8 \mathrm{~cm}$ deep), containing ca. $400 \mathrm{ml}$ of aged tap water, was provided. Egg hatch was observed twice a day ( 9 and $21 \mathrm{~h}$ ). The larvae hatching between 21-9 h were used for experiments.

Field rearing. Larvae were reared in floating cages in the suburbs of Saga City nine times during 1980, 1981 and 1982 (Table 1). From May to October, rice fields in two farms of Faculty of Agriculture, Saga University (Honjo and Shimo-izumi), were used. Both farms were located on the central part of a rice production area developed on the alluvial plain of Saga. There were no apparent differences in rice field conditions among localities or years. Rice was transplanted in middle-late June and harvested in middle-late October. Rice fields were treated with insecticides (usually 3 times), herbicides (once in late June), fungicides ( 3 times) and fertilizers (3 times) and frequently drained of water after August. Rice fields used for larval rearing were not fixed but selected by experiments based on the presence of sufficient water, the absence of evidence of preceding chemical treatments, and accessibility. Two observations, one in the spring (Exp. 8) and one in the autumn (Exp. 9) were done in a swamp near Saga Medical School (Nabeshima), because swamps are a principal larval habitat before and after the rice cultivation season in the Saga area. This swamp also was located on the central part of Saga Plain.

Floating cages of two sizes were used for rearing. Large $(30 \times 30 \times 10 \mathrm{~cm})$ and small $(10 \times 10 \times 10 \mathrm{~cm})$ cloth cages were suspended from $30 \times 30 \mathrm{~cm}$ or $10 \times 10 \mathrm{~cm}$ wire frames attached to the upside of styrofoam floats $(5 \mathrm{~cm}$ in height). Each large and small cage received 40 and 20 larvae, respectively. One large and one small cages were put $1 \mathrm{~m}$ apart, except when the number of hatching larvae was not sufficient to prepare small cages for all the large cages. Cotton-cloth cages, initially used, were replaced by 100-mesh net cages when all the larvae had molted to the third instar. Cages were not covered to ensure fall of organic detritus and airborne particles, which may be important food sources for anopheline larvae.

Small cages were enriched once a day with a mixture of dried yeast and ground pellets for cockroach rearing (ca. 0.04 and $0.2 \mathrm{~g}$ per day for early and late instars, respectively). To prevent fouling of water, food residues on the bottom of cages were removed by a pipette before the addition of food. In contrast, the water in large cages was kept as natural as possible by adding dips of mosquito- and predatorfree water from outside the cages once a day.

Table 1. Rearing of $A n$. sinensis larvae in field cages.

\begin{tabular}{|c|c|c|c|c|c|}
\hline \multirow{2}{*}{ Exp } & \multirow{2}{*}{ Start } & \multirow{2}{*}{ Place* } & \multirow{2}{*}{ Habitat** } & \multicolumn{2}{|c|}{ No. cages } \\
\hline & & & & Natural & Enriched \\
\hline 1 & 24 June 1980 & $\mathrm{H}$ & $\mathrm{R}$ & 5 & 4 \\
\hline 2 & 12 July 1980 & $\mathrm{H}$ & $\mathrm{R}$ & 10 & 8 \\
\hline 3 & 4 Oct. 1980 & $\mathrm{H}$ & $\mathrm{R}$ & 1 & 1 \\
\hline 4 & 26 May 1981 & $\mathrm{~S}$ & $\mathrm{~F}$ & 5 & 5 \\
\hline 5 & 22 June 1981 & $\mathrm{~S}$ & $\mathrm{R}$ & 5 & 5 \\
\hline 6 & 4 July 1981 & $\mathrm{H}$ & $\mathrm{R}$ & 5 & 5 \\
\hline 7 & 9 July 1981 & $\mathrm{H}$ & $\mathrm{R}$ & 4 & 2 \\
\hline 8 & 28 Mar. 1982 & $\mathrm{~N}$ & $\mathrm{~S}$ & 3 & 3 \\
\hline 9 & 12 Oct. 1982 & $\mathrm{~N}$ & $\mathrm{~S}$ & 5 & 5 \\
\hline
\end{tabular}

* H, Honjo; S, Shimo-izumi; N, Nabeshima.

** $\mathrm{R}$, irrigated rice field; $\mathrm{F}$, fallow rice field; $\mathrm{S}$, swamp. 
Daily maximum and minimum temperatures were measured at a depth of $5 \mathrm{~mm}$ by thermometers attached to the underside of styrofoam floats inside large cages. Numbers and stages of survivors and numbers of pupal exuviae were recorded daily. Dead individuals were removed. Air temperature data were obtained from Saga Meteorological Station.

Analyses. Median larval, pupal, and larval instar durations in each cage were determined graphically from 50\% molting time. Statistical procedures followed Sokal and Rohlf (1981) unless otherwise stated. Effects of rearing periods and nutrition on larval and pupal durations were examined by a Model I two-way analysis of variance (ANOVA) for disproportional unequal sample sizes (Snedecor and Cochran, 1967). Because the variances were heterogeneous $(P<0.05$ by Bartlett's test), $\log _{10}$ transformation was performed prior to ANOVA. Some experiments (specified in RESULTS) were excluded from ANOVA but included in regression analyses. Standard error (S.E.) of thermal constants for development ( $K=1 /$ slope of linear regression of developmental velocity on temperature) was calculated as (S.E. of slope)/(slope $)^{2}$, following the delta method (Kuno, 1986).

\section{RESUlTS}

Larval duration. Table 2 shows the mean larval duration for each experiment. In Exp. 6, larvae in all but one natural cage died before pupation due to insecticide treatment. In Exp. 9, observation was discontinued on the 32 nd day due to an accident. At that time, adult emergence had completed in enriched cages, whereas, in natural cages, no adult had emerged and surviving immatures were either pupae $(5-45 \%)$ or larvae. These experiments and Exp. 3 were excluded from ANOVA (Table 3).

Larval durations were affected by rearing periods, nutrition, and their interaction. Larval duration reduction (differ-
Table 2. Larval and pupal durations (day, mean \pm standard deviation) of $A n$. sinensis in field cages. Experiments were arranged by months irrespective of years.

\begin{tabular}{ccclll}
\hline \hline & \multicolumn{2}{c}{ Larva } & & \multicolumn{2}{c}{ Pupa } \\
\cline { 2 - 3 } \cline { 5 - 6 } \cline { 5 - 6 } & Natural & Enriched & & Natural & Enriched \\
\hline 8 & $32.4 \pm 1.3$ & $26.0 \pm 0.2$ & & $2.7 \pm 0.2$ & $3.0 \pm 0.1$ \\
4 & $12.1 \pm 0.8$ & $12.4 \pm 0.5$ & & $1.6 \pm 0.2$ & $1.9 \pm 0.2$ \\
5 & $9.7 \pm 1.0$ & $8.0 \pm 0.3$ & & $2.0 \pm 0.9$ & $2.1 \pm 0.1$ \\
1 & $10.5 \pm 1.3$ & $7.8 \pm 0.4$ & & 1.5 & $2.1 \pm 0.3$ \\
6 & 11.1 & $8.9 \pm 0.5$ & & 0.9 & $1.8 \pm 0.2$ \\
7 & $7.5 \pm 0.4$ & $7.2 \pm 0.1$ & & $1.6 \pm 0.5$ & $1.9 \pm 0.1$ \\
2 & $8.8 \pm 0.7$ & $8.0 \pm 0.5$ & & $2.2 \pm 0.5$ & $2.1 \pm 0.2$ \\
3 & 11.2 & 11.1 & & 3.4 & 3.2 \\
9 & $>32$ & $20.6 \pm 1.2$ & & - & $5.4 \pm 1.8$ \\
\hline
\end{tabular}

Table 3. ANOVA summary table.

\begin{tabular}{lrrc}
\hline \hline \multicolumn{1}{c}{ Source } & \multicolumn{1}{c}{ df } & \multicolumn{1}{c}{$F$} & $P$ \\
\hline Larval duration & & & \\
$\quad$ Period (P) & $5^{*}$ & 309.39 & $<0.001$ \\
Nutrition (N) & 1 & 42.96 & $<0.001$ \\
P $\times$ N & 5 & 5.36 & $<0.001$ \\
Error & 41 & & \\
Pupal duration & & & \\
Period (P) & $4^{* *}$ & 5.72 & $<0.005$ \\
Nutrition (N) & 1 & 1.81 & NS \\
P $\times$ N & 4 & 0.238 & NS \\
Error & 25 & & \\
\hline
\end{tabular}

* Excluding Exp. 3,6 and 9.

** Excluding Exp. 1, 3, 6 and 9. NS, not significant $(P>0.05)$.

ence in mean durations between enriched and natural cages divided the duration in natural cages) by food supply was more than $35 \%$ (=at the time of discontinuance) in Exp. 9 where slowly developing larvae in natural cages were exposed to lower temperatures towards winter. Large reduction also occurred in March (Exp. 8, 20\%), June (Exp. 1, 26\%), and July (Exp. 6, 20\%; Exp. 5, 18\%), thus was not limited to a particular season.

Linear regression of developmental velocity ( $V L$; reciprocal of larval duration in days) on water temperature $(W)$ averaged for the period from the start of field rearing to $50 \%$ pupation was $V L=-0.0615+$ $0.0061 W(F=145.66, \mathrm{df}=1,29, P<0.001)$ for natural cages and $V L=-0.0635+$ $0.0066 \mathrm{~W}(F=147.02, \mathrm{df}=1,33, P<0.001)$ 


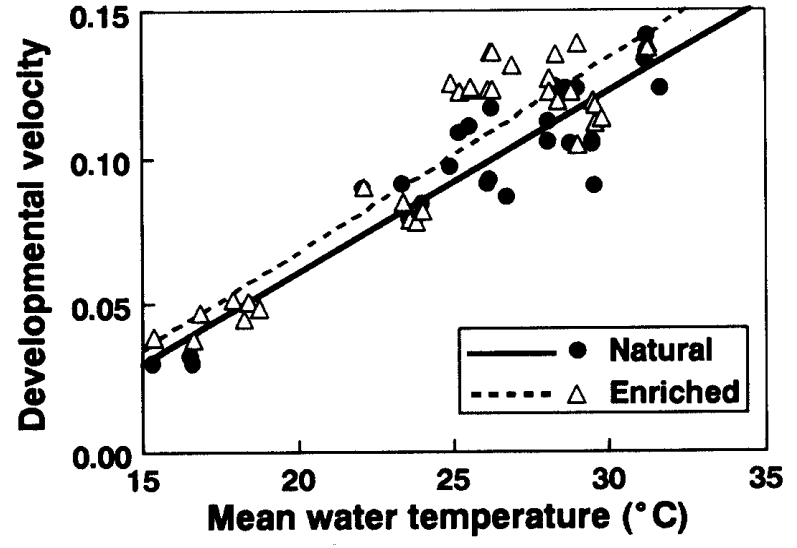

Fig. 1. Relation between mean water temperature and developmental velocity of $A n$. sinensis larvae. for enriched cages (Fig. 1). A developmental threshold $\left(t_{0}\right)$ and a thermal constant $(K \pm$ S.E.) for larvae in natural cages were $10.0^{\circ} \mathrm{C}(95 \%$ confidence interval $=$ $7.0-12.6^{\circ} \mathrm{C}$ ) and $164 \pm 14$ day-degrees, respectively.

Proportions (\%) of instar durations to the whole larval duration regressed on water temperature were not significant in natural cages within the range of ca. 15 $32^{\circ} \mathrm{C}$ (first instar $F=0.517, P>0.25$; second instar $F=2.52, P>0.10$; third instar $F=$ $0.016, P>0.75$; fourth instar $F=0.303, P>$ $0.50 ; \mathrm{df}=1,29$ for all instars) (Fig. 2). For enriched cages, the regression for the fourth instar was significant $(F=13.45$,

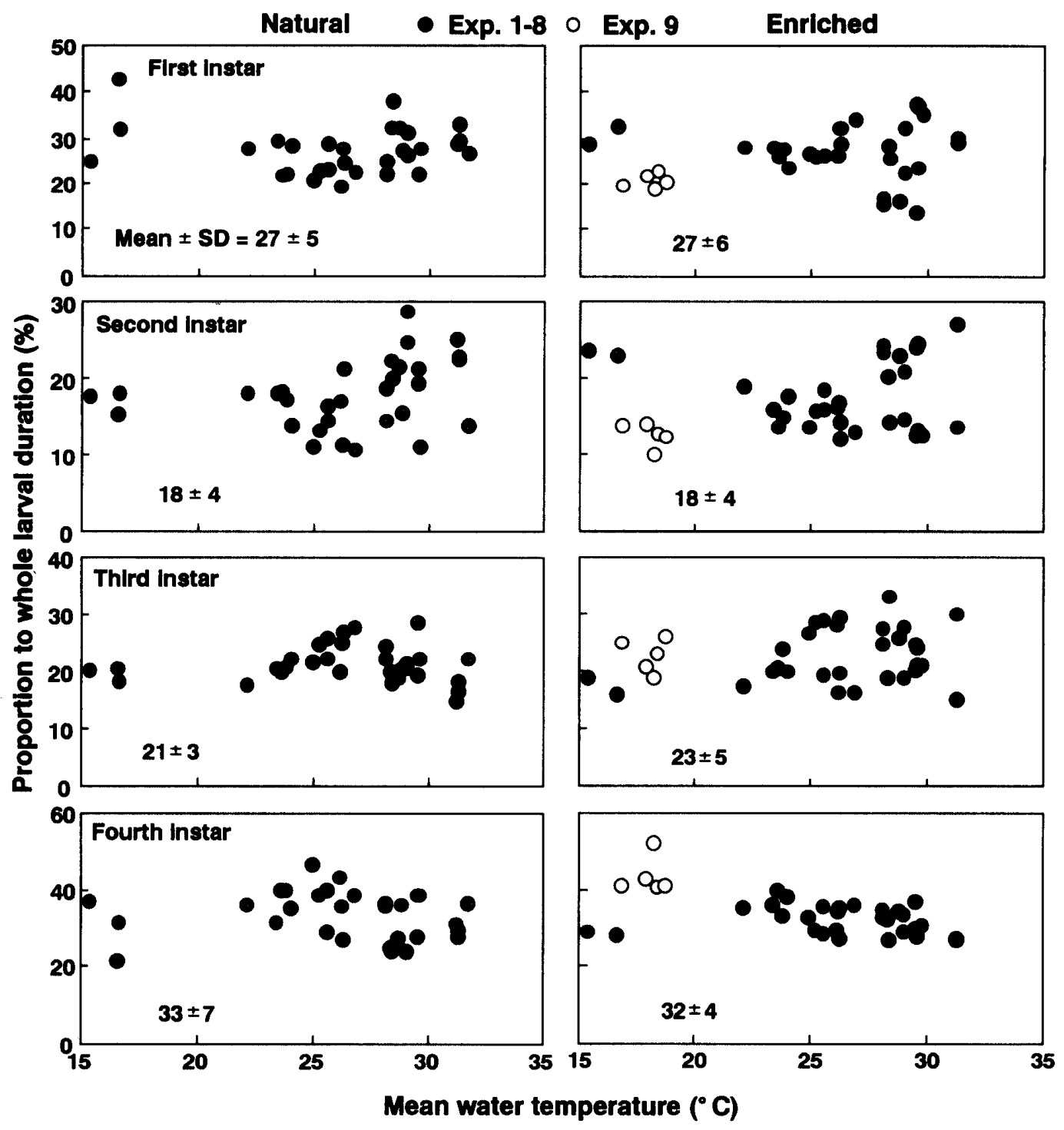

Fig. 2. Relation between mean water temperature and proportional durations of each larval instar. Inserted numerals indicate mean \pm standard deviation. 
$\mathrm{df}=1,33, P<0.001$ ) due to prolonged fourth instar durations under the low temperatures towards winter in Exp. 9. Excluding Exp. 9, the regression for enriched cages also was not significant for all instars (first instar $F=0.253, P>0.50$; second instar $F=0.193, P>0.50$; third instar $F=$ 2.70, $P>0.10$; fourth instar $F=0.546, P>$ 0.25 ; $\mathrm{df}=1,28$ for all instars) (Fig. 2). Mean proportions were similar between natural and enriched cages.

Pupal duration. Mean pupal durations are shown in Table 2. Experiment 1 was also excluded from ANOVA (Table 3 ), because immatures died before adult emergence in all but one cage due to insecticide treatment or drainage of water. Pupal durations were affected by rearing periods, but neither by nutrition nor a period $x$ nutrition interaction.

Linear regression of pupal developmental velocity ( $V P$, natural and enriched cages were combined) on water temperature averaged for the period from $50 \%$ pupation to $50 \%$ adult emergence was $V P=-0.1567+0.026 W \quad(F=38.47, \mathrm{df}=1$, 48, $P<0.001$ ) (Fig. 3). $t_{0}$ and $K \pm$ S.E. for pupae were $6.0^{\circ} \mathrm{C}(95 \%$ confidence inter$\mathrm{val}=-1.9-11.7^{\circ} \mathrm{C}$ ) and $38 \pm 5$ day-degrees, respectively.

The lowest and highest mean temperature from the start of field rearing to $50 \%$ adult emergence were $15.3^{\circ} \mathrm{C}$ (Cage 1 of Exp. 8) and $31.7^{\circ} \mathrm{C}$ (Cage 4 of Exp. 7), respectively. In July (Exp. 2, 6, 7), daily maximum temperatures often exceeded $40^{\circ} \mathrm{C}$.

Water temperature and air temperature. Daily mean water temperature $(W)$ was usually higher than daily mean air temperature $(A)$ (Fig. 4). The relationship between $W$ and $A$ could be expressed by the linear regression $\log _{10} W=0.9402+$ $0.0196 A \quad(F=756.4, \mathrm{df}=1,92, P<0.001)$. The relationship between daily maximum water temperature $(M X W)$ and $A$ also could be expressed by the linear regression $\log _{10} M X W=1.1458+0.0146 A \quad(F=$ 195.2, $\mathrm{df}=1,92, P<0.001)$. This computation followed the procedure for the regres-

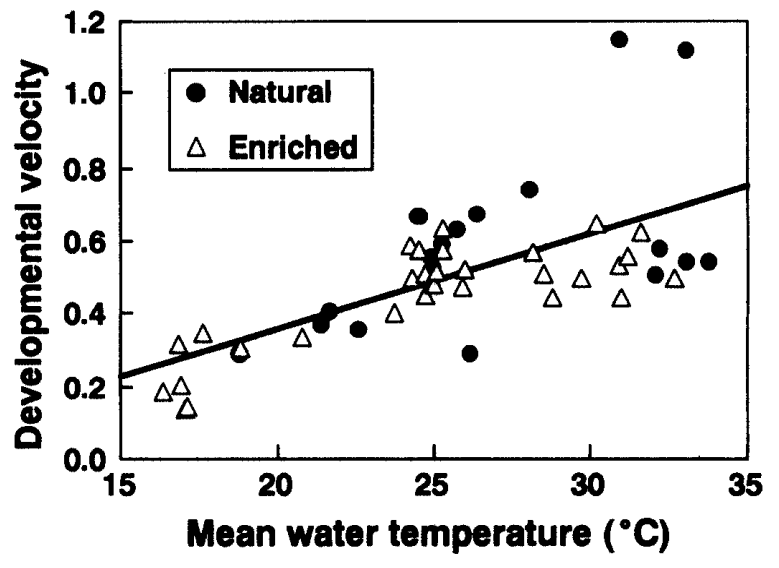

Fig. 3. Relation between mean water temperature and developmental velocity of $A n$. sinensis pupae.
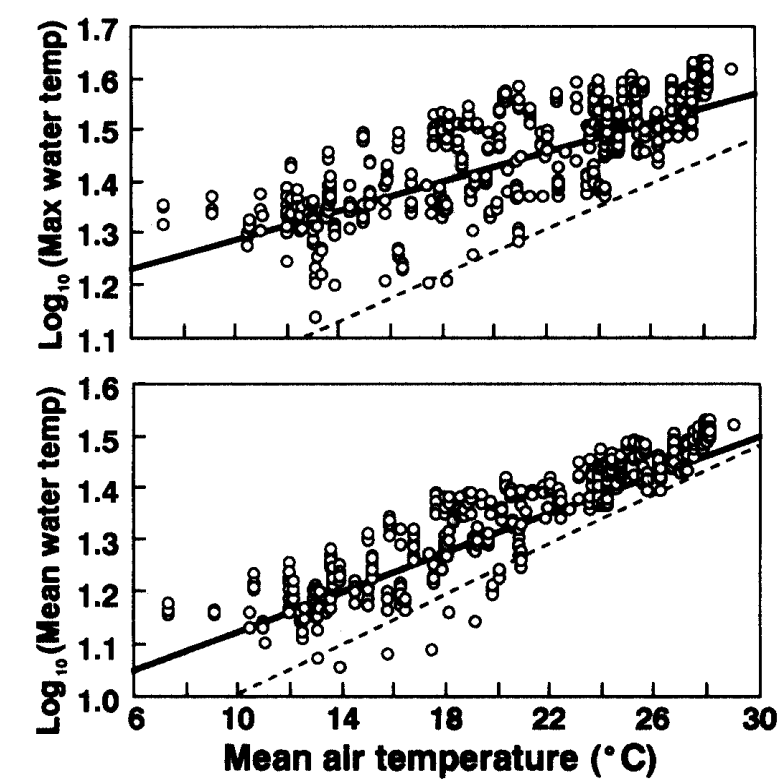

Fig. 4. Relation between mean air temperature and mean or maximum water temperature. Broken line indicates water temperature equal to air temperature.

sion with multiple (unequal size) dependent variable values for a single independent variable value. The total number of data regressed on 94 air temperature values (range $=7.3-29.1^{\circ} \mathrm{C}$ ) was 536 .

\section{Discussion}

Applicability to population analyses. The present results indicate that application of laboratory developmental parameters to anopheline populations in rice fields with shallow, open and often clear 
water needs caution. Firstly, nutrition may be suboptimal in rice fields irrespective of seasons. Probably, the density of organic particles and microorganisms filterable by anopheline larvae at the water surface is affected more by irregular, transient factors (e.g., rainfall, water management, fertilizer treatment) than by regular seasonal factors. Secondly, water temperature is substantially increased by radiant heat in rice fields. In the laboratory, water temperature is usually lower than air temperature, thus differences between water temperatures in rice fields and that in the laboratory could be very large under the same air temperature.

Conditions in our natural cages may have differed from outside conditions with regard to anopheline nutrition. Firstly, enclosure could either increase or decrease the amount of food available to anopheline larvae. Prevention of water surface agitation by enclosure might enhance the development of a surface microlayer enriched with bacteria consumed by anopheline larvae (Walker and Merritt, 1993). On the other hand, isolation of larvae from the bottom and rice plants might reduce access to food. Secondly, crowding effects known from laboratory experiments on anopheline larvae (Reisen, 1975), were excluded from our experiment.

Independence of proportional instar durations from temperatures is inconsistent with laboratory observations for some Anopheles species (Huffaker, 1944; Reisen et al., 1982), but consistent with a field observation for Culex tritaeniorhynchus Giles (Mogi, 1978). Subtle differences, if any, may have been masked with large variations in stage durations in the field.

Local variations in rice cultivation procedures also need to be considered in application of the present results to $A n$. sinensis populations in the field. Rice plants transplanted earlier (for example in May) have become tall and thick in midsummer, therefore may prevent the rise in water temperatures by radiant heat. Flowing irrigation, commonly practiced in terraced rice fields developed along streams in narrow valleys, also may reduce the rise in water temperatures.

Bearing these points in mind, developmental parameters obtained in the natural cages may be utilized for the analysis of $A n$. sinensis immature populations in rice fields on alluvial plains of southwest Japan and managed in a manner similar to that in Saga. Possible procedures are to estimate; (1) rice-field water temperature $(W)$ from air temperature $(A)$ by using an equation $W=10^{0.9402+0.0196 A}$, (2) larval and pupal durations $(D L$ and $D P$ ) by using equations $D L=1 /(0.0061 W-0.0615)$ and $D P=1 /(0.0260 W-0.1567)$, and if necessary, (3) each larval instar duration by proportional allotment of the larval duration $(0.27,0.18,0.21$ and 0.33 for first through fourth instar).

Winter activity in north Kyusyu under climate change: an example of predictive use. In the temperate region, $A n$. sinensis overwinters as adult females in ovarian diapause induced by low temperature and short daylength conditions (Oda et al., 1988). However, their primary follicles develop to stage Ib and females may take blood on warmer days in January in north Kyushu (Oda et al., 1988; Wada et al., 1973). The mean air temperatures in north Kyushu is $5-6^{\circ} \mathrm{C}$ in January. By extrapolating our empirical equations to this temperature range, we obtain estimates of mean $\left(10.9-11.4^{\circ} \mathrm{C}\right)$ and mean maximum $\left(16.5-17.1^{\circ} \mathrm{C}\right)$ water temperatures. The mean water temperature is close to $t_{0}$ for larval development, but the larvae hatching in January could develop during the sunny daytime. However, 13 days of snow in January and February (the mean in Saga for 1961-1990) would be lethal to $A n$. sinensis immatures. The temperature rise by doubling atmospheric $\mathrm{CO}_{2}$ concentration is predicted to be within $1.5-4.5^{\circ} \mathrm{C}$ for the global mean with larger increments at higher latitudes and in winter. If we take $5^{\circ} \mathrm{C}$ predicted by either Geophysical Fluids Dy namics Labor- 
atory or United Kingdom Meteorological Office as the increment of the winter mean in the north temperate region including Japan (Mitchell et al., 1990), the expected January mean in north Kyushu is 10$11^{\circ} \mathrm{C}$. Under these temperatures comparable to current late March, there would be no snow and we have $13.7-14.3^{\circ} \mathrm{C}$ and $19.6-20.2^{\circ} \mathrm{C}$ as estimates of mean and mean maximum water temperatures. Thus, we can predict that $A n$. sinensis immatures can develop in north Kyushu under $5^{\circ} \mathrm{C}$ warming in January, even though its physiological attributes remain unchanged.

However, this prediction does not necessarily mean the appearance of adult populations high enough to cause medical and veterinary problems in midwinter, because, under such low temperatures, adult emergence rates will be low due to mortality accumulated during extended immature development. In fact, $A n$. sinensis larvae were present but rare in midwinter on Tanegashima, an island south of Kyushu and on the temperate-subtropical border, where the January mean temperature is currently $11^{\circ} \mathrm{C}$ (Mogi, 1996). Comprehensive population parameters such as $r$ (intrinsic rate of natural increase) could give more realistic predictions about impact of global warming on mosquito populations.

\section{ACKNOWLEDGMENTS}

We thank N. Tanaka, T. Shozaki and H. Tanaka for permission to use rice fields of Saga University.

\section{REFERENCES}

Harrison, B. A. and J. E. Scanlon (1975) Medical entomology studies-II. The subgenus Anopheles in Thailand (Diptera: Culicidae). Contrib. Am. Entomol. Inst., 12(1): 1-307.

Huffaker, C. B. (1944) The temperature relations of the immature stages of the malarial mosquito, Anopheles quadrimaculatus Say, with a comparison of the developmental power of constant and variable temperatures in insect metabolism. Ann. Entomol.
Soc. Am., 37: 1-27.

Kuno, E. (1986) Methods to study dynamics of animal populations I, 114 pp., Kyoritsu Shuppan Inc., Tokyo (in Japanese).

Mitchell, J. F. B., S. Manabe, V. Meleshko and T. Tokioka (1990) Equilibrium climate change-and its implications for the future. In: Climate change (ed., Houghton, J. T., G. J. Jenkins and J. J. Ephraums), pp. 131-172, Cambridge University Press, New York.

Mogi, M. (1978) Population studies on mosquitoes in the rice field area of Nagasaki, Japan, especially on Culex tritaeniorhynchus. Trop. Med., 20: 173-263.

Mogi, M. (1996) Overwintering strategies of mosquitoes (Diptera: Culicidae) on warmer islands may predict impact of global warming on Kyushu, Japan. J. Med. Entomol., 33: 438-444.

Mogi, M., I. Miyagi and B. D. Cabrera (1984) Development and survival of immature mosquitoes (Diptera: Culicidae) in Philippine rice fields. J. Med. Entomol., 21: 283-291.

Mogi, M., T. Okazawa, I. Miyagi, S. Sucharit, W. Tumrasvin, T. Deesin and C. Khamboonruang (1986) Development and survival of anopheline immatures (Diptera: Culicidae) in rice fields in northern Thailand. J. Med. Entomol., 23: 244-250.

Oda, T., K. Kurokawa, A. Mori, M. Ueda, M. Zaitsu, O. Suenaga and K. Uchida (1988) Studies on gonoactivity and overwintering of the mosquito, Anopheles sinensis Wiedemann in Nagasaki area. Bull. Sch. Allied Med. Sci. Nagasaki Univ., 2: 25-35.

Reisen, W. K. (1975) Intraspecific competition in Anopheles stephensi Liston. Mosq. News, 35: 473482.

Reisen, W. K., K. Azra and F. Mahmood (1982) Anopheles culicifacies (Diptera: Culicidae): horizontal and vertical estimates of immature development and survivorship in rural Punjab Province, Pakistan. J. Med. Entomol., 19: 413-422.

Snedecor, G. W. and W. G. Cochran (1967) Statistical methods, 6th ed., 593 pp., Iowa State University Press, Ames.

Sokal, R. R. and F. J. Rohlf (1981) Biometry, 2nd ed., 859 pp., Freeman, New York.

Wada, Y., T. Oda, M. Mogi, O. Suenaga, I. Miyagi, N. Omori, S. Ito and J. Nishigaki (1973) Ecology of vector mosquitoes of Japanese encephalitis, especially of Culex tritaeniorhynchus summorosus. 5. Overwintering of Culex tritaeniorhynchus summorosus and Anopheles sinensis. Trop. Med., 15: 11-22.

Walker, E. D. and R. H. Merritt (1993) Bacterial enrichment in the surface microlayer of an Ano- 
pheles quadrimaculatus (Diptera: Culicidae) larval habitat. J. Med. Entomol., 30: 1050-1052.

World Health Organization (WHO) (1989) Geographical distribution of arthropod-borne diseases and their principal vectors. VBC/89.967. WHO, Geneva.

World Health Organization (WHO) (1990) Potential health effects of climatic change. Rep. WHO task group. PEP/90.10. WHO, Geneva.

\section{摘要}

野外におけるシナハマダラカ幼虫の発育：

温度と栄養条件の影響

茂木幹義岡沢孝雄

佐賀医科大学微生物学教室

（于849 佐賀市鍋島 5-1-1）
佐賀市の水田または湿地に浮かべた網枠の中で 3-11 月にシナハマダラカ幼虫を飼育し，その発育を調べた. 幼虫期間は網枠内への餌の添加により短縮し，野外では 郋不足条件下にあることが示された。，幼虫の発育限界温 度と発育に要する有効積算温度は, おのおの, 約 $10^{\circ} \mathrm{C}$ と 164 日度, 蛹のそれは約 $6^{\circ} \mathrm{C}$ と 38 日度であった. 全 幼虫期間に対する幼虫各齢期間の割合は, 温度と栄養条 件に影響されなかった。旦平均気温から水田水表（ハマ ダラカ幼虫の生息場所）の日平均又は日最高水温を推定 する経験式を与えた。 